\title{
Effect of Parental Education on the Intrinsic Motivation of Higher Secondary Students of Contai Subdivision, East Medinipur of West Bengal
}

\author{
Avijit Bera ${ }^{1}$, Lalkrishna Khanra ${ }^{2}$ \\ ${ }^{1}$ Research Scholar of Magadh University, Bodhgaya \\ ${ }^{2}$ Assistant Professor of Education, Mahishadal Girls College, West Bengal.
}

\begin{abstract}
A comprehensive study on the effects of parental education on students intrinsic motivation in education in higher secondary level. Parents are parameterized in two category, mainly graduate and non graduate. On the basis of intrinsic motivation inventory the study is carried on the students of three Bengali medium school of Contai sub- division, East Medinipur, West Bengal. Seven different null hypothesis are tested in statistical method. It is found that five null hypothesis are accepted, and two null hypothesis is rejected. Importance of parental education on the intrinsic motivation of students in education is reflected very necessary. It is also found that very high and very low parental education has adverse effect on students intrinsic motivation in education.
\end{abstract}

Keywords: Intrinsic motivation, parental education, reflection, higher secondary education, intrinsic motivation inventory

\section{Introduction}

The word education has a very wide connotation and it is difficult to give its precise definition. A Biologist, a Priest, a Psychologist, a Philosopher, a Statesman , a Teacher , a Merchant, a Shopkeeper, and even an artisan - all of them supposed to be having intelligence - will give widely different definitions. These definitions whether naive or serious- determined by their own outlook on life, developed through training they had and the circumstances they were in , instead of being contradictory are complementary to one at the other . Education is an indispensable element of human existence. It is a special effort as well as special achievement of man. Education is not only a term or concept . Man gradually started forming societies for satisfying his social and psychological needs . He started acquiring knowledge about the various aspects of leading a happy life . He started giving proper attention to his materialistic needs , proper expression and communication of his feeling and desires, development of his mental capacities and abilities. According to Vivekananda "Education is the manifestation of perfection already in man."

Parents brought up their children, parent influence has strong effect on the education attainments of students . Parental education helps on higher secondary students to create intrinsic motivation. Intrinsic motivation is an essential elements in learning of higher secondary students.

\section{Objective of the Study}

A problem should be studied with some objectives . A researcher should know the objectives of her research . Hence the objectives of the study can be more explicitly presented as-

1) To study the effect of total high and total low parental education on the intrinsic motivation of higher secondary students in Contai Subdivision.
2) To study the effect of high and low parental education on the intrinsic motivation of Higher Secondary girls in Contai Subdivision .

3) To study the effect of high parental education and low parental education on the intrinsic motivation of higher secondary boys in Contai Subdivision.

4) To study the effect of high parental education of Higher Secondary boys and girls on their intrinsic motivation in Contai Subdivision.

5) To study the effect of low parental education of Higher Secondary boys and girls on their intrinsic motivation in Contai Subdivision

\section{Formulation of the Hypothesis}

Hypotheses are not ends in themselves, rather they are means by which the investigator can understand the problem with greater clarity and ramification, as well as the data which bear on it. It acts as a framework for the conclusion and permits the collection of relevant data and that makes possible the interpretation of these data in the light of potential solution.

\section{The following Hypotheses are -}

$\mathbf{H}_{\mathbf{1}}$ - There exist significance difference between the intrinsic motivation of higher secondary students having high parental education and low parental education

$\mathbf{H}_{2}$ - There exist significance difference between the intrinsic motivation of higher secondary girls having high parental education and higher secondary girls having low parental education.

$\mathbf{H}_{3}$ - There exist significant difference between the intrinsic motivation of higher secondary boys having high parental education and higher secondary boys having low parental education.

$\mathbf{H}_{\mathbf{4}}$ - There exist significant difference between the intrinsic motivation of higher secondary boys having high parental education and higher secondary girls having high parental education. 


\section{International Journal of Science and Research (IJSR) \\ ISSN (Online): 2319-7064}

Index Copernicus Value (2013): 6.14 | Impact Factor (2014): 5.611

$\mathbf{H}_{5}$ - There exist significant difference between the intrinsic motivation of higher secondary boys having low parental education and higher secondary girls having low parental education.

$\mathbf{H}_{6}$ - There exist significant difference between the intrinsic motivation of higher secondary boys having high parental education and higher secondary girls having low parental education.

$\mathbf{H}_{7 \text { - }}$ There exist significant difference between the intrinsic motivation of higher secondary girls having high parental education and higher secondary boys having low parental education.

\section{The following null hypothesis are-}

$\mathbf{H}_{\mathbf{O} 1}$ - There exist no significance difference between the intrinsic motivation of higher secondary students having high parental education and low parental education .

$\mathbf{H}_{\mathbf{O} 2}$ - There exist no significance difference between the intrinsic motivation of higher secondary girls having high parental education and higher secondary girls having low parental education.

$\mathbf{H}_{\mathbf{O} 3}$ - There exist no significant difference between the intrinsic motivation of higher secondary boys having high parental education and higher secondary boys having low parental education.

$\mathbf{H}_{\mathbf{O} 4}$ - There exist no significant difference between the intrinsic motivation of higher secondary boys having high parental education and higher secondary girls having high parental education.

$\mathbf{H}_{\mathbf{O 5}^{-}}$There exist no significant difference between the intrinsic motivation of higher secondary boys having low parental education and higher secondary girls having low parental education.

$\mathbf{H}_{\mathbf{0 6}}$ - There exist no significant difference between the intrinsic motivation of higher secondary boys having high parental education and higher secondary girls having low parental education.

$\mathbf{H}_{\text {07- }}$ There exist no significant difference between the intrinsic motivation of higher secondary girls having high parental education and higher secondary boys having low parental education.

\section{Methodology of the Study}

\subsection{Method}

Survey method of Descriptive research has been followed in the study.

\subsection{Population}

The universe of present investigation is the higher secondary school of Contai sub-division.The whole sample is collected from xi and xii students of three selected Bengali medium school of Contai sub- division.

Table 1: Total number of students studying in xi and xii class of selected schools

\begin{tabular}{|r|c|c|c|c|}
\hline No. & Name of School & Boys & Girls & Total \\
\hline 1 & Chak-Rasul I.N. Siksha Niketan & 35 & 24 & 59 \\
\hline 2 & Sarpai Model Institution & 37 & 28 & 65 \\
\hline 3 & Kayemgeria D.M. High School & 47 & 29 & 76 \\
\hline
\end{tabular}

\subsection{Tools and techniques}

For the measurement of the effect of parental education on the intrinsic motivation of higher secondary students . I select Deci and Ryan's (1985, 2000) tool for this study. This investigator has used a Bengali translated version of the Intrinsic Motivation Inventory (IMI) which has been translated and standardized by Roy (2008) constructed by Deci and Ryan (1985). This is a multidimensional flexible tool that determines subjectse level of intrinsic motivation with the help of interest/enjoyment, perceived competence, effort, value/ usefulness, felt pressure and tension, and perceived choice . The present Bengali adapted version of the IMI contains 52 items, both positive and negative .

\section{Scoring Principle}

The Bengali version of the IMI is a 52 -item, 3 point Likerttype tool with three response alternatives. The three alternatives are supposed to stand on three points of a psychological continuum expressing subjects $^{\text {ee }}$ normal behavior with regard to intrinsic motivation underpinned by a specific item stated in a form of brief statement. The response alternatives are labeled as „Agree", „Undecided and ,Disagree ${ }^{\text {ec }}$ and the assigned weights are $, 3^{\text {ee }},, 2^{\text {ec }}$, and, $1^{\text {ee }}$ respectively.

\section{Reliability Studies}

Internal consistency and stability of the IMI are given below.

\section{Internal Consistency (Cronbach's Alpha)}

Internal consistency of the sub-scale has been determined by the various researchers. The obtained Cronbaches alpha of the sub-scales are in Table- 2

Table 2: Cronbach 's a s for each Dimension of the (Bengali) IMI

\begin{tabular}{|c|c|c|c|c|c|c|c|}
\hline $\begin{array}{c}\text { Interest/ } \\
\text { Enjoyment }\end{array}$ & $\begin{array}{c}\text { Perceived } \\
\text { competence. }\end{array}$ & $\begin{array}{c}\text { Effort/ } \\
\text { Importance. }\end{array}$ & $\begin{array}{c}\text { Pressure/ } \\
\text { Tension }\end{array}$ & $\begin{array}{c}\text { Perceived. } \\
\text { Choice }\end{array}$ & $\begin{array}{c}\text { Value/ } \\
\text { Usefulness }\end{array}$ & Relatedness. & Researchers \\
\hline 0.78 & 0.80 & 0.84 & 0.68 & - & - & - & McAuley et al., 1989 \\
\hline 0.97 & - & 0.91 & - & - & 0.69 & - & Foreman, 2005 \\
\hline 0.91 & 0.82 & 0.80 & 0.88 & - & - & - & Wiechman, 2007 \\
\hline 0.87 & 0.89 & 0.84 & 0.88 & 0.86 & 0.88 & 0.86 & Roy, 2008 \\
\hline
\end{tabular}

The alpha values shown above are highly satisfactory indicating internal consistency of the sub scales of the IMI
Stability (Test-retest Reliability) The reliability coefficient of the IMI determined by Roy (2008) with the help of test-retest method is being shown in Table-3 


\section{International Journal of Science and Research (IJSR) \\ ISSN (Online): 2319-7064}

Index Copernicus Value (2013): 6.14 | Impact Factor (2014): 5.611

Table 3: Test-Retest Reliability Coefficient of IMI $[\mathrm{N}=95$, Interval $=4$ Weeks $]$

\begin{tabular}{|c|c|c|c|c|c|c|c|}
\hline $\begin{array}{c}\text { Interest/ } \\
\text { Enjoyment }\end{array}$ & $\begin{array}{c}\text { Perceived } \\
\text { competence. }\end{array}$ & $\begin{array}{c}\text { Effort/ } \\
\text { Importance. }\end{array}$ & $\begin{array}{c}\text { Pressure/ } \\
\text { Tension }\end{array}$ & $\begin{array}{c}\text { Perceived. } \\
\text { Choice }\end{array}$ & $\begin{array}{c}\text { Value/ } \\
\text { Usefulness }\end{array}$ & Relatedness. & Researchers \\
\hline 0.79 & 0.86 & 0.80 & 0.82 & 0.78 & 0.81 & 0.78 & Roy, 2008 \\
\hline
\end{tabular}

The values of test-retest are high enough and significant to ensure satisfactory stability of each dimension of the test.

\subsection{Procedure of Data Collection}

Based on hypothesis on selected topic, data were generated via self- completion questionnaire use of Deci and Ryan's (1985, 2000) tool, of the elected school during the period from $03 / 05 / 2015$ to $15 / 05 / 2015$. After the data collection each of the tools was scored as per as respected guideline and the statistical test performed included analysis of frequencies, mean score, t-test. All finding reported were statistically significant to at least 0.01 and 0.05 level.

\section{Analysis and interpretation of data:}

Analysis of data is a process of inspecting, cleaning, transforming, and modeling data with the goal of highlighting useful information, suggesting conclusions and supporting decision making. Data analysis has multiple facets and approaches, encompassing divers techniques under a variety of names, in different business, science and social science domains.

Data analysis is a process, within which several phases can be distinguished. Statistical data analysis divides the methods for analyzing data into two categories: exploratory methods and confirmatory methods . Exploratory methods are used to discover that the data seems to be saying by using simple arithmetic and easy-to-draw pictures to summarize data . Confirmatory methods use ideas from probability theory in the attempt to answer specific questions . Probability is important in decision making because it provides a mechanism for measuring, expressing, and analyzing the uncertainties associated with future events.

A p-value is a measure of how much evidence you have . One may combine the p-value with the significance level to make decision on a given test of hypothesis.

For testing normality Skewness and Kurtosis have been measured. The results show nearly normal (Skeness-.089 and Kurtosis-.312). Therefore, for analysis of the data the investigator has used t-test for significance of the results. The analysis is given below according to the hypothesis

Table 4: Two sample t-test high parental education vs. low parental education

\begin{tabular}{|c|c|c|c|c|c|}
\hline $\begin{array}{c}\text { Parental } \\
\text { education }\end{array}$ & $\begin{array}{c}\text { No. of } \\
\text { data }\end{array}$ & Mean & $\begin{array}{c}\text { Standard } \\
\text { deviation }\end{array}$ & t value & $\begin{array}{c}\text { P } \\
\text { value }\end{array}$ \\
\hline $\begin{array}{c}\text { High parental } \\
\text { education }\end{array}$ & 100 & 128.2 & 20.2 & 12.06 & 0.000 \\
\cline { 1 - 3 } $\begin{array}{c}\text { Low parental } \\
\text { education }\end{array}$ & 100 & 95.5 & 17.9 & & \\
\hline \multicolumn{7}{|c|}{ df =195 } \\
\hline
\end{tabular}

$\mathbf{H}_{1}$ - From table- 4 it is observed that mean score of higher secondary students having high parental education is found to be 128.0. while mean score of higher secondary students having low parental education is pound to be 95.5 and standard Deviation between these two were found to be 20.2 and 17.9 respectively . T-value was 12.06 which is significant at 0.01 and 0.05 levels for degree of freedom 195 i.e the null hypothesis is rejected. Therefore the alternative hypothesis is accepted i.e. there is significant difference in the intrinsic motivation level of higher secondary students having high parental education and low parental education. Hence the hypothesis $H_{1}$ is accepted .

Table 5: Two sample t-test for girls high parental education vs girls low parental education

\begin{tabular}{|c|c|c|c|c|c|}
\hline $\begin{array}{c}\text { Parental } \\
\text { education }\end{array}$ & $\begin{array}{c}\text { No. of } \\
\text { data }\end{array}$ & Mean & $\begin{array}{c}\text { Standard } \\
\text { deviation }\end{array}$ & $\begin{array}{c}\mathrm{t} \\
\text { value }\end{array}$ & $\begin{array}{c}\mathrm{P} \\
\text { value }\end{array}$ \\
\hline $\begin{array}{c}\text { High parental } \\
\text { education (girls) }\end{array}$ & 39 & 126.0 & 23.3 & 6.47 & 0.000 \\
\cline { 1 - 4 } $\begin{array}{c}\text { Low parental } \\
\text { education(girls) }\end{array}$ & 42 & 96.7 & 16.6 & & \\
\hline \multicolumn{5}{|c|}{$\mathbf{d f}=\mathbf{6 8}$} \\
\hline
\end{tabular}

$\mathbf{H}_{2}$-From table- 5 it is observed that mean score of higher secondary girls having high parental education is found to be 126.0 . While mean score of higher secondary girl student having parental education is found to be 96.7 and standard deviation between these two were found to be 23.3 and 16.6 respectively . $\mathrm{T}$ value between there two was 6.47 significant at 0.01 and 0.05 level for degree of freedom 68 . i.e. is the null hypothesis is rejected. Therefore the alternative hypothesis is accepted i.e. there is significant difference in the intrinsic motivation level of girl higher secondary students having high parental education and girl higher secondary students having low parental education . Hence the hypothesis $\mathrm{H}_{2}$ is accepted .

Table 6: Two sample t-test for boys high parental education vs. boys low parental education

\begin{tabular}{|c|c|c|c|c|c|}
\hline $\begin{array}{c}\text { Parental } \\
\text { education }\end{array}$ & $\begin{array}{c}\text { No. of } \\
\text { data }\end{array}$ & Mean & $\begin{array}{c}\text { Standard } \\
\text { deviation }\end{array}$ & value & $\begin{array}{c}P \\
\text { value }\end{array}$ \\
\hline $\begin{array}{c}\text { High parental } \\
\text { education (boys) }\end{array}$ & 62 & 128.8 & 18.3 & 9.99 & 0.000 \\
\hline $\begin{array}{c}\text { Low parental } \\
\text { education(boys) }\end{array}$ & 57 & 94.6 & 19.0 & & \\
\hline \multicolumn{7}{|c|}{$\mathbf{d f}=\mathbf{1 1 5}$} \\
\hline
\end{tabular}

$\mathbf{H}_{3}$-From table -6 it is observed that mean score of higher secondary boy students having high parental education is found to be 128.8 . While mean score of higher secondary boy students having low parental education is found to be 94.6 and standard deviation between these two were found to be 18.3 and 19.0 respectively . T- value between there two was 9.99 significant at 0.01 and 0.05 level for degree of freedom 115 i.e. the null hypotheses is rejected. Therefore the alternative hypotheses is accepted i.e. there is significant difference in the intrinsic motivation level of boy higher secondary students having high parental education and boy higher secondary students having low parental education.

Hence the hypothesis $\mathrm{H} 3$ is accepted . 


\section{International Journal of Science and Research (IJSR) \\ ISSN (Online): 2319-7064 \\ Index Copernicus Value (2013): 6.14 | Impact Factor (2014): 5.611}

Table 7: Two sample t-test for boys high parental educaton vs girls high parental education

\begin{tabular}{|c|c|c|c|c|c|}
\hline $\begin{array}{c}\text { Parental } \\
\text { education }\end{array}$ & $\begin{array}{c}\text { No. of } \\
\text { data }\end{array}$ & Mean & $\begin{array}{c}\text { Standard } \\
\text { deviation }\end{array}$ & $\begin{array}{c}t \\
\text { value }\end{array}$ & $\begin{array}{c}P \\
\text { value }\end{array}$ \\
\hline $\begin{array}{c}\text { High parental } \\
\text { education (boys) }\end{array}$ & 62 & 128.8 & 18.3 & 0.63 & 0.532 \\
\cline { 1 - 3 } $\begin{array}{c}\text { High parental } \\
\text { education (girls) }\end{array}$ & 39 & 126.0 & 23.3 & & \\
\hline \multicolumn{5}{|c|}{$\mathbf{d f}=\mathbf{6 6}$} \\
\hline
\end{tabular}

$\mathbf{H}_{4}$ - From table-7 it is observed that mean score of higher secondary boys having parental education is found to be 128.8. While mean score of higher secondary girl students having high parental education is found to be 126.0 and standard deviation between these two were found to be 18.3 and 23.3 respectively . T- value between there two was 0.63 insignificant at 0.01 and 0.05 level for degree of freedom 66 i.e. the null hypothesis is accepted . Therefore the alternative hypothesis is rejected i.e. there is no significant difference in the intrinsic motivation level of boy higher secondary students having high parental education and girl higher secondary students having high parental education .Hence the hypothesis $\mathrm{H}_{4}$ is rejected.

Table 8: Two sample T test for boys low parental education vs girl low parental education.

\begin{tabular}{|c|c|c|c|c|c|}
\hline Parental education & $\begin{array}{c}\text { No. of } \\
\text { data. }\end{array}$ & Mean & $\begin{array}{c}\text { Standard } \\
\text { deviation }\end{array}$ & $\begin{array}{c}t \\
\text { value }\end{array}$ & $\begin{array}{c}P \\
\text { value }\end{array}$ \\
\hline $\begin{array}{c}\text { Low parental } \\
\text { education (boys) }\end{array}$ & 57 & 94.6 & 19.0 & 0.61 & 0.546 \\
\hline $\begin{array}{c}\text { Low parental } \\
\text { education (girls) }\end{array}$ & 42 & 96.7 & 16.6 & & \\
\hline \multicolumn{7}{|c|}{$\mathbf{d f}=\mathbf{9 4}$} \\
\hline
\end{tabular}

$\mathbf{H}_{5}$-From table-8 it is observed that mean score of higher secondary boy students having low parental education is found to be 94.6 . While mean score of higher secondary girl students having low parental education is found to be 96.7 and standard deviation between these two were found to be 19.0 and 16.6 respectively . $\mathrm{T}$ value between there two was 0.61 insignificant at 0.01 and 0.05 level for degree of freedom 94 i.e. the null hypothesis is accepted . Therefore the alternative hypothesis is rejected i.e. there is no significant difference in the intrinsic motivation level of higher secondary boys having low parental education and higher secondary girls having low parental education. Hence the hypothesis $\mathrm{H}_{5}$ is rejected.

Table 9: Two sample t-test for boys high parental education vs girl low parental education.

\begin{tabular}{|c|c|c|c|c|c|}
\hline $\begin{array}{c}\text { Parental } \\
\text { education }\end{array}$ & $\begin{array}{c}\text { No. of } \\
\text { data }\end{array}$ & Mean & $\begin{array}{c}\text { Standard } \\
\text { deviation }\end{array}$ & $\begin{array}{c}t \\
\text { value }\end{array}$ & $\begin{array}{c}P \\
\text { value }\end{array}$ \\
\hline $\begin{array}{c}\text { High parental } \\
\text { education(boys) }\end{array}$ & 62 & 128.8 & 18.3 & 9.27 & 0.000 \\
\hline $\begin{array}{c}\text { Low parental } \\
\text { education(girls) }\end{array}$ & 42 & 96.7 & 16.6 & & \\
\hline \multicolumn{7}{|c|}{$\mathbf{d f}=\mathbf{9 3}$} \\
\hline
\end{tabular}

$\mathbf{H}_{6}$-From table-9 it is observed that mean score of higher secondary boy students having high parental education is found to be 128.8 . While mean score of higher secondary girl students low parental education is found two be 96.7 and standard deviation between these two were found to be 18.3 and 16.6 respectively . T- value between there two was 9.27 significant at 0.01 and 0.05 level for degree of freedom 93 i.e. the null hypothesis is rejected i.e. there is significant difference in the intrinsic motivation level of higher secondary students boys having high parental education and higher secondary girls having low parental education. Hence the hypothesis $\mathrm{H} 6$ is accepted .

Table 10: Two sample t-test for girls high parental education vs boys low parental education.

\begin{tabular}{|c|c|c|c|c|c|}
\hline Parental education & $\begin{array}{c}\text { No. of } \\
\text { data }\end{array}$ & Mean & $\begin{array}{c}\text { Standard } \\
\text { deviation }\end{array}$ & $\begin{array}{c}\mathrm{t} \\
\text { value }\end{array}$ & $\begin{array}{c}\mathrm{P} \\
\text { value }\end{array}$ \\
\hline $\begin{array}{c}\text { High Parental } \\
\text { education (girls) }\end{array}$ & 39 & 126.0 & 23.3 & & \\
\hline $\begin{array}{c}\text { Low Parental } \\
\text { education (boys) }\end{array}$ & 57 & 94.6 & 19.0 & 6.98 & 0.000 \\
\hline \multicolumn{6}{|c|}{$\mathrm{df}=70$} \\
\hline
\end{tabular}

$\mathbf{H}_{7}$. From table-10 it is observed that mean score of higher secondary girl students having high parental education is found to be 126.0 .While mean score of higher secondary boy students having low parental education is found to be 94.6 and standard deviation between these two were found to be 23.3 and 19.0 respectively . T- value between there two was 6.98 significant at 0.01 and 0.05 level for degree of freedom 70 i.e. the null hypothesis is rejected. Therefore the alternative hypothesis is accepted i.e. there is significant difference in the intrinsic motivation level of higher secondary girls having high parental education and higher secondary boys having low parental education. Hence the hypothesis $\mathrm{H}_{7}$ is accepted .

\section{Discussion and Conclusion}

A present study examined effect of parental education on the intrinsic motivation of higher secondary students reflection in their professional development activities. Across all of the data discussed above, improving parental performance, professional development growth, appear to be the most important determinates to the intrinsic motivation of higher secondary students. One of the most significant findings there exist significance difference between the intrinsic motivation of higher secondary students having high parental education and low parental education. Also important findings of parental education on the intrinsic motivation as a very useful tool that effects higher secondary students motivation. Lack of time, lack of parental knowledge, lack of teachers, lack of proper conducive environments, lack of students guidance as the most important obstacles for implementing.

Finally as an exploratory study in a field that is under research I suggest the following points for the parents.

1. Parents are the first teacher for the child, so parents should provide proper conducive environment for the development of their intrinsic motivation.

2. Parents should attend to the needs and desires of the child and if it is right they should try to fulfill it.

3. Parents should not compare their child negatively with others.

4. Parents should compare their child positively with others.

5. Parents should not be harsh in giving and kind of instructions to them. 


\section{International Journal of Science and Research (IJSR) \\ ISSN (Online): 2319-7064 \\ Index Copernicus Value (2013): 6.14 | Impact Factor (2014): 5.611}

6. The relationship between the child and the parents should be positive and jovial one.

\section{References}

[1] Cassidy, S et al .(1991). “ Developmental Psychology "New York : Holt Rinehart and Winston Inc (p.711723).

[2] Deci \& Ryan $(1985,2000)$. Intrinsic Motivation (Relevant Tool ,Bengali Version).

[3] Eccles, J. S et al.(1998). "Motivation to succeed" New York: In W .Damon and N. Eisenberg (Eds). Handbook of Child Psychology (p: 95)

[4] Gold Berg M D (1994) . "A developmental investigation of consequences in high ability students " Dissertation abstract international , 55, 0413-1688.

[5] Gottfried, A.E. (1990). "Academic intrinsic motivation in young elementary school children" Journal of Education Psychology 82 (3), (525-538) .

[6] Hammer ,B.(2003) . "Motivation and student achievement " Washington : Harper and Row Publishers(p.107).
[7] Higbee, J . C. (1996) . "Ability, preparation, or motivation" Research and Teaching in Developmental Education (p. 93).

[8] Howse, R. B. (1999). "Motivation and self- regulation as predictors of achievement in economically disadvantaged young children" Dissertation Abstract International, 60-66B .

[9] Koul Lokesh (2009) . "Methodology of Education Research( 4th Edition).

[10] Lytton , H . (1971). "Creativity and Education" London: Department of educational psychology Company limited (p. 101).

[11] Mitchell ,J.V. Jr.(1992). "Interrelationships and predictive efficacy for intrinsic of intrinsic extrinsic ,and self -assessed motivation for learning " Journal of Research and in Education 25(3),149-155.

[12] Moula, J. M. (2010): "A study of the relationship between academic achievement motivation and home environment among standard eight pupils " published by Educational Research and Reviews Vol. 5 (5),pp.213-217 , May, Available online at www.academicjournals.org ISSN 1990-3839, 2010.

[13] Niebuhr K. (1995). "Psychology of the classroom" London: Methuen and Co (p. 109)

\section{APPENDIX- 1}

\section{INTRIVSICMOTIVATION INVENTORY}

Name: Name of the school:

Class: Sex: Male/Female

Parental education qualification: Graduate/Non graduate

\section{Instruction}

This is a test of intrinsic motivation questioner there are 52 statements relating to this inventory. Any students answer own opinion and putting a tick mark $(\sqrt{ })$ against any one of the following three alternatives ,,surely true ${ }^{\text {ee }}$, ,undecided ,e $^{\text {,e }}$,surely false ${ }^{\text {ee }}$ and the assigned weights are $, 3^{\mathrm{ec}},, 2^{\mathrm{ec}}$, and, $1^{\mathrm{ce}}$.

\begin{tabular}{|c|c|c|c|c|}
\hline 1 & I enjoy the course & 3 & 2 & 1 \\
\hline 2 & I enjoy the studying the course & 3 & 2 & 1 \\
\hline 3 & I have interested in learning all paper that I have to study & 3 & 2 & 1 \\
\hline 4 & Class lecture to be more & 3 & 2 & 1 \\
\hline 5 & Attending school regularly gives me much enjoyment as I can learn more & 3 & 2 & 1 \\
\hline 6 & Studying at library give me wonderful academic experience & 3 & 2 & 1 \\
\hline 7 & I find joining the course is interesting & 3 & 2 & 1 \\
\hline 8 & I think there is no other interesting place than my school & 3 & 2 & 1 \\
\hline 9 & While I engage in studying I think about how much shall I enjoy from the course & 3 & 2 & 1 \\
\hline 10 & Text books hold my attention at all & 3 & 2 & 1 \\
\hline 11 & I think I am pretty good at my school & 3 & 2 & 1 \\
\hline 12 & I think am pretty good in communication skill & 3 & 2 & 1 \\
\hline 13 & $\begin{array}{c}\text { Curriculum of my course will help me to be more competent in the subject } \\
\end{array}$ & 3 & 2 & 1 \\
\hline 14 & Knowledge that can I gather undergoing the course will give me to get a good college for undergraduate study & 3 & 2 & 1 \\
\hline 15 & The course work will find me independent in life. & 3 & 2 & 1 \\
\hline 16 & Studying in the course will help me academically proficient & 3 & 2 & 1 \\
\hline 17 & I understand the course materials very well, compared to others. & 3 & 2 & 1 \\
\hline 18 & I put a lot of effort into studying & 3 & 2 & 1 \\
\hline 19 & I usually do not try to hard to get good grade & 3 & 2 & 1 \\
\hline 20 & I put much emphasis on regular study & 3 & 2 & 1 \\
\hline 21 & I never forget to undergo regular study & 3 & 2 & 1 \\
\hline 22 & I am lazy at studying & 3 & 2 & 1 \\
\hline 23 & I try my best to put my all energy to invest in studying & 3 & 2 & 1 \\
\hline 24 & Good grade has a special meaning to me and I never think to get poor score in any subject at all & 3 & 2 & 1 \\
\hline 25 & I put every effort and concentration to follow class lectures fully & 3 & 2 & 1 \\
\hline 26 & Academic success is my mission of life & 3 & 2 & 1 \\
\hline
\end{tabular}




\section{International Journal of Science and Research (IJSR) \\ ISSN (Online): 2319-7064}

Index Copernicus Value (2013): 6.14 | Impact Factor (2014): 5.611

\begin{tabular}{|l|l|l|l|l|}
\hline 27 & I never think, listening class lecture is important & 3 & 2 & 1 \\
\hline 28 & I do not feel nervous while doing exam. preparation & 3 & 2 & 1 \\
\hline 29 & I feel tensed while doing best in studying & 3 & 2 & 1 \\
\hline 30 & I feel pressurized while completing daily assignment daily & 3 & 2 & 1 \\
\hline 31 & I feel I have choice in undergoing learning & 3 & 2 & 1 \\
\hline 32 & I undergo studying as I have no other choice & 3 & 2 & 1 \\
\hline 33 & I do hard and I myself set my programmed & 3 & 2 & 1 \\
\hline 34 & I enjoy my freedom in organizing my studying & 3 & 2 & 1 \\
\hline 35 & I have no choice in learning, my teachers just control the matter & 3 & 2 & 1 \\
\hline 36 & I have much choice in organizing my learning the subject & 3 & 2 & 1 \\
\hline 37 & I think that I have some choice in joining the course and continuing it. & 3 & 2 & 1 \\
\hline 38 & I join the course, as I wanted it & 3 & 2 & 1 \\
\hline 39 & I believe studying the course real value & 3 & & 1 \\
\hline 40 & Studying the course will help me lot in future & 3 & 2 & 1 \\
\hline 41 & I am confident that after completing the course I shall get lift in career & 3 & 2 & 1 \\
\hline 42 & Studying the subject will give me valuable skills & 3 & 2 & 1 \\
\hline 43 & Studying the course is just wastage of resources-time, money and energy & 3 & 2 & 1 \\
\hline 44 & I hope I must learn useful skills to orient my life & 3 & 2 & 1 \\
\hline 45 & The course will give me important information to learn and transfer them in new situation & 3 & 2 & 1 \\
\hline 46 & Knowledge derived from the course will empower us much & 3 & 2 & 1 \\
\hline 47 & I feel very close to my teachers & 3 & 1 \\
\hline 48 & I enjoy group activities in the classroom & 2 & 1 \\
\hline 49 & I feel alone in the classroom & 3 & 2 & 1 \\
\hline 50 & School is too formal without human concern for human beings & 3 & 2 & 1 \\
\hline 51 & Teachers guide me intimately when I need & 2 & 1 \\
\hline 52 & & 2 & 1 \\
\hline
\end{tabular}

\section{Appendix-2}

Answer Table

\begin{tabular}{|c|c|c|c|}
\hline \multirow[t]{2}{*}{ Dimensions } & \multicolumn{2}{|c|}{ Number of Items } & \multirow{2}{*}{$\begin{array}{c}\text { Total No. } \\
\text { of Items }\end{array}$} \\
\hline & Old Sl. No. & New Sl. No. & \\
\hline 1) Interest / Enjoyment & $1,2,3,4,5,6,7,8,9,10$ & $1,2,3,4,5,6,7,8,9,10$ & 10 \\
\hline 2)Perceived Competence & $11,12,13,14,15,16,17$ & $11,12,13,14,15,16,17$ & 7 \\
\hline 3) Effort/Importance & $18,19,20,21,22,23,24,25,26,27$. & $18, \underline{19}, 20,1, \underline{22}, 23,24,25,26, \underline{27}$. & 10 \\
\hline 4) Pressure / Tension & $\underline{28}, 29, \underline{30}$ & $28, \underline{\underline{29}}, \underline{30}$ & 3 \\
\hline 5) Perceived Choice & 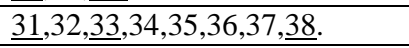 & $31,32,33,34,35,36,37,38$. & 8 \\
\hline 6) Value / Usefulness & $39,40,41,42,43,44,45, \underline{46}$. & $39,40,41,42,43,44,45,46$. & 8 \\
\hline 7) Relatedness & $47,48,49,50,51,52$ & $47,48, \underline{49}, \underline{50}, \underline{51}, 52$ & 6 \\
\hline
\end{tabular}

N.B.: Underlined Items are keyed the Negative Items. 